\title{
A Study of the Cash Flow Forecasting Impact on the Owners Financial Management of Construction Projects in the State of Kuwait
}

\author{
Moustafa Kotb ${ }^{1}$, Mohamed Abdel Razik Ibrahim ${ }^{1} \&$ Yousef Saleh Al-Olayan ${ }^{1}$ \\ ${ }^{1}$ Faculty of Engineering, Al-Azhar University, Cairo, Egypt \\ Correspondence: Yousef Saleh Al-Olayan, Graduate Student at the Faculty of Engineering, Al-Azhar University, \\ Cairo, Egypt.
}

Received: March 12, 2018

Accepted: March 22, 2018

Online Published: March 26, 2018

doi:10.20849/abr.v3i1.351

URL: https://doi.org/10.20849/abr.v3i1.351

\begin{abstract}
Cash flow is considered to be the main acceleration's factor of any construction contract, which has a large and direct impact on projects completion dates as well as the project contractual duration. This is very evident when examining how the owners benefit from their projects in achieving or forfeiting the desired economic feasibility determined in the feasibility study of any project.

It is noted that the cash flow plan is issued through a Critical Path Method (CPM) for a project which entails only an estimate of the monetary value of the construction work to be carried out on site and on a rough and approximate basis using the cash flow's curve (S-CURVE), which is usually gives a different value from the actual work performed onsite.

The impact of this problem on financial management for any project is as follows:

In the case of underestimation, if the available estimates are less than the required cash flow, it is considered as a major cause for delay in project completion as well as the inability of the owner to achieve the economic feasibility Internal Rate of Return (IRR) required for the project. Also, this leads to monitory error due to the financial compensations due to the contractor as a result of the damage caused by time extensions due to the holdings of the cash entitlements.

In the case of overestimation of the value of the required cash flow with a high margin of error, this leads to the monetary waste of amounts that could have been invested in other ventures, projects or opportunities.

This paper provides a summary of the importance of determining the appropriate amount of cash flows required to be provided by the owner's financial management, which leads to achieving the appropriate projects financial management gains and thus reducing financial losses or disputes in construction projects in the State of Kuwait.
\end{abstract}

Keywords: construction, cash flow forecasting, financial management, project acceleration, feasibility study, S-CURVE, CPM, progress payments, contract disputes, project control

\section{Introduction}

Construction projects are known to be large in complexity and not generally controlled, which leads to increasing their risk due to high execution costs. The poor financial management of these projects in providing the outstanding payment amounts on time due may lead to delayed completion and thus failure to meet its economic feasibility, which causes the owners significant financial losses. Therefore, prior knowledge of the actual cash flow values required during the construction phases is of paramount importance (Khosrowshahi, F. and Kaka 2007).

It is also noted that the main instrument used by any financial management department to estimate the actual cash flows due for a project throughout the implementation phase is the project financial cash flow curve (S-CURVE). However, the project S-CURV prepared at the beginning of the project does not represent the actual or real amounts actually owed.

It actually represents the planned work on site without taking into account neither the actual increase nor decrease in the works nor the materials stored on site, and therefore does not represent the actual cash flow necessary to be provided by the financial management department in accordance with the progress payment certificate (Zayed and Liu, (2014). 
It is common practice that financial departments set an emergency contingency ratio for projected progress payments to take account of any increase or decrease in planned cash flows to cover the difference between the expected S-CURVE and the actual work performed on site.

In the case of underestimation, this may result in a lack of cash available to cover outstanding payments. This will result in a slowdown in the contractors performed work on site as a result of the lack of sufficient payments for the work done, which inevitably leads to delays in execution and performance as well as leading to the eligibility of the contractor for financial compensation and time extension. This will certainly be a major financial burden on the owner, which is neither calculated nor determined in the feasibility study, and this delay in time will lead inevitably to the reduction of the internal rate of return (IRR), which will lead to failure to achieve the return of the feasibility study (Odeyinka, Lowe and Kaka, (2008).

In the case of overestimating the contingency - taken from the available liquidity - to estimate the value of progress payment due, this increase is simply a waste of investment funds by wasting other investment opportunities ready to exploit instead of the wrong and overestimation of progress payments (Odeyinka, Lowe and Kaka, (2008).

In either case, there is a vital need for a sound and effective financial management tool in construction projects to predict the actual cash flow required to maintain the feasibility of the owner's projects.

There is currently no appropriate financial instrument or cash flow forecasting system that can be relied upon on a daily basis to facilitate accurate knowledge of payment certificates before they are received from the Engineer.

This paper examines the extent to which the project's financial management team can predict the value of progress payments of actual work performed on site in accordance with the traditional regulations currently in use in construction projects in Kuwait.

This paper also highlights the effectiveness of the current financial management systems in projects and their ability to provide an appropriate tool to estimate progress payments before receiving them from the Engineer, which contributes to reducing future dispute opportunities resulting from delays due to insufficient funding available for progress payments.

The dispute between contracting parties has long been part of this industry, as the vast majority of project dispute cases relate to the problems of time delay and its financial effects on the owners. As can be seen from the large number of dispute cases before Kuwaiti courts and arbitral tribunals, this clearly reflects the inability to identify and address the time and financial deviations of the contract in a timely manner during the implementation phase. In spite of the large number of large-scale projects and the previous experience of working in such projects, the prior knowledge of the amounts actually owed is still a problem faced by the financial management teams of the contracting parties, especially owners. (Akintoye, Beck, Hardcastle,Chinyio, and Assenova (2001)

Therefore, the objective of this paper is to discuss the importance of the owner's prior knowledge of the cash flows dues properly and in close proximity to the reality, alongside with discussing the consequences of poor financial management throughout the project execution phase.

\section{Research Objectives}

This study aims to give the project stakeholders the possibility of identifying problems as they occur and taking the immediate measures necessary to stop the aggravation of these problems by using standard financial cash flow forecasting tool or system. The question is: Do we need it or not? Using surveys for different parties, the answer will appear. By using the next methodology, we will reach the two main objectives;

1. Financial cash flow forecasting tool or system importance.

2. Characteristics of suggested cash flow forecasting tool.

\section{Research Methodology}

The research methodology consists of three main steps:

\section{A. Observation}

\section{B. Data Collection}

\section{Data Analysis \& Results}

We are going to use questionnaire procedures in order to observe the market needs for the different construction industrial parties. There parties are Public sector owners, private sector owners, Construction Management firms, Design/Supervision Consultants \& Contractors (public, private) 


\section{Requirement for Effective Financial Cash Flow Forecasting Tool in Construction Industry}

\subsection{Observation}

It is clear from the large number of disputes in front of the courts and arbitral tribunals, that the parties to the contract are unable to identify and address the time and financial deviations of the contract, in a timely manner during the implementation phase due to the poor management of the project and the loss of the parameters of the conflict. We also discovered that the next element could be major reasons for the previous states

- Lack of professional archiving of documents.

- The facts of the dispute are not substantiated.

- Failure to address the problem in a timely manner and take the appropriate action, which missed the opportunity to avoid that conflict in time and before the aggravation by taking the necessary action in a timely manner.

\subsection{Data Collection}

A questionnaire was prepared from 100 citizens and residents of Kuwait in their various forms of this type of industry (Figure 1), which are related to various projects, which are mostly construction projects or real estate investment projects. The different forms of their relationship with these projects give an objective picture of the need for this search. This sample included the following:

- 25 employees of senior management in government bodies as representatives of employers.

- 15 employees of private sector companies as representatives of employers.

- 15 employees in the administrative bodies as representatives of project management.

- 15 workers in the role and consulting offices.

- 30 senior management personnel of local and international contracting companies in the Gulf region in general and Kuwait in particular.

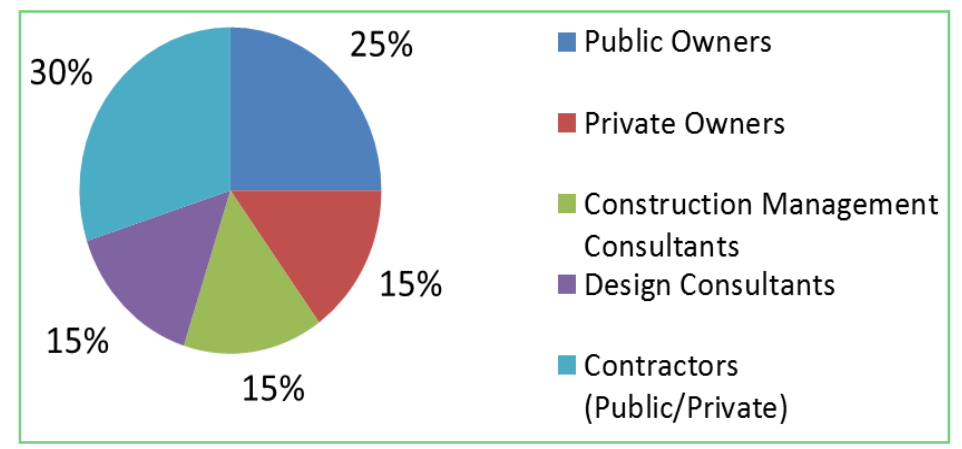

Figure 1. Study participants by project role

\section{The selected sample was asked the following questions:}

Q1- Can the finance department determine the amount of the actual work done on site on daily basis cumulatively before receiving the payment certificate from the Engineer?

The response for Q1 can be summarized in the following table:

\begin{tabular}{llllllll}
\hline Sample & Don't Know & None & Weak & Good & Very Good & Excellent \\
\hline Public Owners & 2 & 23 & 0 & 0 & 0 & 0 & 0 \\
\hline Private Owners & 0 & 14 & 1 & 0 & 0 & 0 & 0 \\
\hline PM firms & 4 & 9 & 2 & 0 & 0 & 0 & 0 \\
\hline Engineering firms & 2 & 12 & 1 & 0 & 0 & 0 & \\
\hline Contractors & 2 & 23 & 5 & 0 & 0 & $\mathbf{0}$ & \\
\hline Total & $\mathbf{1 0}$ & $\mathbf{8 1}$ & $\mathbf{9}$ & $\mathbf{0}$ & $\mathbf{0}$
\end{tabular}


Q2- Since payment certificates include materials stored on site, is it possible to know if the materials stored on site have been delivered and stored on site for the purpose of using it for actually works need or only to claim financial liquidity from the owner?

The response for Q2 can be summarized in the following table:

\begin{tabular}{lllll}
\hline Sample & Don't Know & No & Yes & The Percentage of Possibility \\
\hline Public Owners & 5 & 19 & 1 & $4 \%$ \\
\hline Private Owners & 8 & 6 & 1 & $7 \%$ \\
\hline PM firms & 9 & 4 & 2 & $13 \%$ \\
\hline Engineering firms & 8 & 6 & 1 & $7 \%$ \\
\hline Contractors & 6 & 19 & 5 & $17 \%$ \\
\hline TOTAL & $\mathbf{3 6}$ & $\mathbf{5 4}$ & $\mathbf{1 0}$ & $\mathbf{1 0} \%$ \\
\hline
\end{tabular}

Q3- If the answer for the previous question (Don't Know, NO, Yes) how can the owner verify that? (You can choose more than one verifying way).

The response for Q3 can be summarized in the following table:

\begin{tabular}{lllllll}
\hline Ways of Verification & $\begin{array}{l}\text { Public } \\
\text { Owner }\end{array}$ & $\begin{array}{l}\text { Prvt. } \\
\text { Owner }\end{array}$ & PM Firms & $\begin{array}{l}\text { Engr. } \\
\text { Firms }\end{array}$ & $\begin{array}{l}\text { Cont - } \\
\text { ractors }\end{array}$ & TOTAL \\
\hline Don't know & 5 & 8 & 9 & 8 & 6 & $\mathbf{3 6}$ \\
\hline That is impossible & 19 & 6 & 4 & 6 & 19 & $\mathbf{5 4}$ \\
\hline By asking the owner staff & 1 & 1 & 0 & 0 & 0 & $\mathbf{2}$ \\
\hline $\begin{array}{l}\text { No need for verification; } \\
\text { contractor is trustworthy }\end{array}$ & 0 & 0 & 0 & 0 & 5 & $\mathbf{5}$ \\
\hline By asking the Project Mngr. & 5 & 8 & 2 & 8 & 6 & $\mathbf{2 9}$ \\
\hline By asking the consultant & 5 & 8 & 9 & 1 & 6 & $\mathbf{2 9}$ \\
\hline TOTAL & & & & & $\mathbf{1 5 5}$ \\
\hline
\end{tabular}

\subsection{Data Analysis \& Results}

By analyzing the results of the questionnaire survey for each participant group. It can be summarized in the following table:

\begin{tabular}{|c|c|c|c|c|c|c|c|}
\hline \multirow[b]{2}{*}{$\mathbf{Q}$} & \multirow[b]{2}{*}{ Financial Management } & \multicolumn{5}{|c|}{ Percentage of Ability } & \multirow[b]{2}{*}{$\begin{array}{l}\text { Average of } \\
\text { Perc-entage }\end{array}$} \\
\hline & & $\begin{array}{l}\text { Public } \\
\text { Owner }\end{array}$ & $\begin{array}{l}\text { Private } \\
\text { Owner }\end{array}$ & $\begin{array}{l}\text { PM } \\
\text { Firms }\end{array}$ & $\begin{array}{l}\text { Eng. } \\
\text { Firms }\end{array}$ & $\begin{array}{l}\text { Cont- } \\
\text { ractor }\end{array}$ & \\
\hline 1 & $\begin{array}{l}\text { The ability of the finance department to } \\
\text { determine the actual cash flow due at any point } \\
\text { of time during the execution duration }\end{array}$ & $0 \%$ & $0 \%$ & $0 \%$ & $0 \%$ & $0 \%$ & $\mathbf{0 \%}$ \\
\hline 2 & $\begin{array}{l}\text { The possibility to know if material stored on } \\
\text { site is for the purpose of site works needs or } \\
\text { only to claim financial liquidity from the owner }\end{array}$ & $4 \%$ & $7 \%$ & $13 \%$ & $7 \%$ & $17 \%$ & $10 \%$ \\
\hline \multirow{8}{*}{3} & \multicolumn{5}{|c|}{$\begin{array}{l}\text { Way of how the owner verifying The material stored on site if it is for site } \\
\text { works needs or only to claim financial liquidity from the owner }\end{array}$} & Total & $\begin{array}{l}\text { Percentage } \\
\text { of each way }\end{array}$ \\
\hline & \multicolumn{5}{|l|}{ Don’t know } & 36 & $23 \%$ \\
\hline & \multicolumn{5}{|l|}{ That is impossible } & 54 & $35 \%$ \\
\hline & \multicolumn{5}{|l|}{ By asking the owner staff } & 2 & $1 \%$ \\
\hline & \multicolumn{5}{|l|}{ No need for verification ; contractor is trustworthy } & 5 & $3 \%$ \\
\hline & \multicolumn{5}{|l|}{ By asking the Project Manager } & 29 & $19 \%$ \\
\hline & \multicolumn{5}{|l|}{ By asking the consultant } & 29 & $19 \%$ \\
\hline & \multicolumn{5}{|l|}{ Total } & 155 & $100 \%$ \\
\hline
\end{tabular}


It can be concluded from the parties answer and its analysis (mentioned in the previous tables) the following essential facts:

1. All parties agreed that there is no ability to verify the amount due of the actual executed work on the site at any point of time during construction.

2. The majority of parties involved in this study agreed that there is no clear way to verify if the materials supplied to site are specific to the project or are intended to be used for another project, with the contractor's intention is to collect cash only, where most answers were under the category of Don't Know or NO.

The information and mechanism required to find the cash amounts owed are only those shown in the planned cash flow curve (S-CURVE), which usually does not reflect the actual value payable of finished work and materials stored on site. This highlights the importance of the role of the financial management in the public and private sectors in achieving projects on their deadlines, through the ability to identify and provide due amounts and payments in a timely manner.

However, it is clear from the traditional role of the finance department by analyzing the questionnaire data of participants in this research study, that there are general common problems to all parties involved in the project who also suffer from the non-activeness of the financial management role in this regard and its negative effects from the absence of an effective cash flow forecasting system in a more accurate manner, which affects the outcome of the feasibility of the project by not knowing nor providing the necessary financial cash allocation in a timely manner.

This is an expected result of the absence of a simple and practical construction system in the construction industry that is easy to set up for determining the daily cash flow of projects related to the actual work carried out on the site on a daily basis. Such system can be prepared and applied by the financial management department and trusted by all concerned parties in a scientific and methodical manner.

It is clear from the party's responses and the survey's result as shown in the tables above the important need of a financial management tool to control all the finance issues in construction projects.

\section{Conclusion}

As a result, there is a growing need for a simplified model that can be prepared by all contracting parties, including the finance department of all parties, to monitor and determine the daily cash flow based on the actual performance of the site work plus the value of the materials stored on site at any given time.

Therefore it is essential to have a proper financial management tool and report that has the following features:

1. It can be issued by any party specifically by the finance department of all parties.

2. Easy and fast to prepare by engineers or non-engineers at any given time.

3. The agreement of all parties on its content.

4. Short and easy to read by engineers or non-engineers.

5. The form should be simple, easy and abbreviated to read the vocabulary from it.

6. The accuracy of the model's information, not its size, is the most important aspect;

7. The ability to assess the financial and actual situation of the project;

\section{References}

Akintoye, A., Beck, M., Hardcastle, C., Chinyio, E. \& Assenova, D. (2001). Framework for risk assessment and management of private finance initiative projects. Report of an EPSRC Sponsored Research Project (pp. 10). Glasgow Caledonian University, Glasgow.

Khosrowshahi, F., \& Kaka, A. P. (2007). A Decision Support Model for Construction Cash Flow Management.

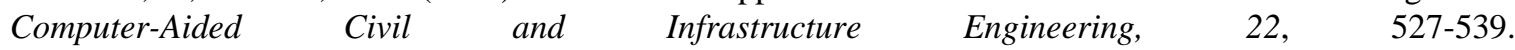
https://doi.org/10.1111/j.1467-8667.2007.00508.x

Tarek Zayed, \& Yaqiong Liu. (2014). Cash flow modeling for construction projects. Engineering, Construction and Architectural Management, 21(2), 170-189. https://doi.org/10.1108/ECAM-08-2012-0082

\section{Copyrights}

Copyright for this article is retained by the author(s), with first publication rights granted to the journal.

This is an open-access article distributed under the terms and conditions of the Creative Commons Attribution license (http://creativecommons.org/licenses/by/4.0/). 